\title{
放射線抵抗性腫瘍症例について
}

$\begin{array}{llll}\text { 果大耳鼻科 } & \text { 高 } & \text { 橋 } & \text { 由美子 } \\ \text { 果大医科研放射線科 } & \text { 熊 沢 昭 良 }\end{array}$

上顎癌の機能保存治療の目的は発病前と同じ生 活をさせる事で, 三者併用も最近は開洞時減量操

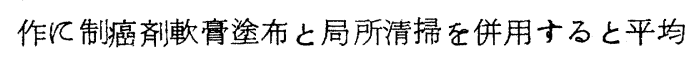
$800 \mathrm{rad}$ 照射ですんでいる。との治療を教え てくれをものと放射線抵抗性腫瘍症例がある。

37 才女, 線維肉腫は暗赤色の柔い腫瘍で, 照 射と部切をた中鼻甲介の残存腫瘍子切除し, 再発 転移もなくもとどおり生活している。

46 才男, 黒色腫は褐色の暗点がある黒く污い 腫瘍で鼻中隔・下鼻甲介から鼻咽頭に拡がってい た。照射・動注・部切の三者併用を行い, 中隔の 残存腫瘍は混合ガス吸入時照射ですんでいる。

37才男, 経過の長い骨肉腫は上顎全摘を勧め られ転科してきた。減量操作したが再発を繰返す 為, 混合ガスあるいは速中性子照射と外来清掃で 腫瘍を制御し社会復帰している。

17 才, 神経線維肉腫は赤く球状の腫瘍で照 射と部切を行い, その後再三再発は通学しながら 外来清掃を続けている。

67才女, 髓膜腫はCTSCanで mass を指摘 され転科してをた。1回照射後, 上顎開洞と側頭 裔の軟い小顆柆状の腫瘍を除去し脳内腫瑒壮混合 ガス吸入時照射でおちつを全身状態, 精神状態と ると改善している。

68 年以降の放射線坻抗性腫瘍 15 例を立女 ると組織分類は多彩で既治療例も少くないが治療 線量は 1,400 rad 照射例が多く動注しなかっ た1 症例西る。再発は外来清掃を主としてい るが, 再三再発を繰返す治療抵抗性のものは、混 合ガス吸入時照射と積極的外来清掃で形態と機能 を保存している。

以上ををとめると，放射線抵抗性腫煬が機能保 存治療を教えてくれた。組織診壮多彩で既治療例
ああるが, 個々の症例で臨床像の違いと経過を観 ながら治療配量を決め, 再発もしつとく外来処置 すると, 広範囲進展例でる形態と機能を保存して 発病前と同じ生活を楽しく続け, 結果的には生存 率も向上している。つまり, 機能保存治療は成績 の向上と両立する。

\section{質問今野昭義（秋田大 耳鼻科）}

混合ガス常圧下吸入時照射, 速中性子照射飞 上って放射性抵抗性腫瘍も治癒するとの報告で あるが, Lineac x線照射, ${ }^{60} \mathrm{Co}$ 照射ではいか がですか。

\section{答佐藤靖雄 (東大)}

治療に再三抵抗する腫瘍や顔皮膚にも侵潤し 穿孔しそらな場合は, 混合ガス常圧下吸入時照 射と飞, 中性子照射と積極的外来清掃と併用 している。混合ガス日1回400 rad て腫瘍 及び周囲組織の反応が強いから, 洞側より, 壊 死や脱落傾向の腫瘍を除去している。

速中性子は1回80〜100 rad て 低酸素 性細胞にも ${ }^{60} \mathrm{C} ○$ より効果があるが，乙れだけで はなく,壤死を除去し, 血液をよくするなど, 補 助操作が必要である。

诈問 松村瓳二郎（九州がんセンター）

速中性子は質的に、コバルトなどと異なると 思い专すが, 量的には従来のものの涪何倍位 の強さをもっているのでしょらか。

\section{答佐藤靖雄（東大）}

速中性子 $80 \sim 100 \mathrm{rad}$ で テレコバルト $200 \mathrm{rad}$ 亿相当するようです。

但し, 速中性子は, 低酸素性癌細胞飞効果 があるをめ, テレコバルトより利用価值が高い, 
しかし周囲組織の反応る強いから注意を要する。 頸部転移等には有用である。

質問高橋㕕臣（北里）

細胞肉腫にはもら少し照射したらどらか。

答高橋由美子(東大)

1）15症例の中に細網肉腫はありません。 神経線維肉腫のととでしょらか。

2) 混合ガス吸入時, 照射は, 再三再発を繰 返す症例や頸部リンパ節転移に著効を示し てい李す。翌日同教室の者が詳しく報告し ます。

答佐藤靖雄 (東大)

既組織診（細網肉腫）をつけて来院した17 才女子高校生は, 口腔前庭に赤く球状の軟腫 瘍で,むしろ臨床的にはリンパ肉腫に近いかと 考えたが, 照射効果が低々ので腫瘍減量操作し た 一 神経線維肉腫であった。その後再三再 発時の組織診は線維肉腫でもある。同一腫浣で も, 組織猃は, 誰がみたがよっても報告が違 らことがある。同一腫瘍塊の部位によっても差 があるが, 臨床医は臨床像の違いと経過をみわ けるととが大切である。 